\title{
Chauvireria bulgarica sp. n. - an extinct Early Pleistocene small phasianid of Phasianinae Horsfield, 1821 from Bulgaria
}

\author{
Zlatozar Boev
}

National Museum of Natural History, Bulgarian Academy of Sciences, 1 Tsar Osvoboditel Blvd, 1000 Sofia, Bulgaria, boev@nmnhs.com, zlatozarboev@gmail.com

http://zoobank.org/4899A23A-498D-4F53-819B-173E275195F7

\begin{abstract}
A new species of small phasianid is described, based on 54 bone findings of 21 skeletal elements of forelimb and pectoral girdle (9) and hindlimb and pelvic girdle (12) representing at least four individuals. The holotype is the scapula. The new species differs from the type species (Chauvireria balcanica Boev, 1998) of the genus by: (1) the longer acromion scapulae, which is more upright and dorsally instead of cranially directed, (2) the thinner humeral part of the coracoid, and (3) the wider condylus dorsalis of the humerus. The species probably inhabited rocky, open shrubby and dry habitats in the middle Villafranchian (Villanyian; first half of MNQ 18 a; 2.1-1.95 Mya) in western Bulgaria.
\end{abstract}

Keywords: Quaternary birds, Slivnitsa locality, Villafranchian fauna, Villanyian

\section{Introduction}

Small phasianids (Phasianinae Horsfield, 1821) are a highly diversified group of gallinaceous birds, both in recent and fossil faunal assemblages. They inhabit a wide range of habitats, both of open and forested landscapes. Recent world fauna of small phasianids (former Perdicinae) numbers 106 species (McCowan, 1994). The fossil record of the subfamily after Brodkorb (1964) covers at least 24 species. Bochenski (1997) lists ca. 38 species only in Europe, while Mlíkovský (2002) reduces their number to 14 species (of Cenozoic).

\section{Description of the Slivnitsa locality site}

The material was collected from a stockpile - a landfill containing a rock mass of a blasted cave (karst cavern) in Jurassic limestone. According to Spassov (1997), the even distribution of finds of the same species of large and small mammals, the uniform fossilisation of the bones and the homogeneity of the faunistic mammalian complex confirm the chronological identity of the palaeozoological material. The existence of a former cave where the remains had been accumulated was also confirmed by the presence of fragments of stalactites.

Terrestrial vertebrates of over 40 taxa have been identified so far in the locality. Amphibians (frogs and toads) and reptiles (snakes and lizards) are not numerous. After preliminary identifications by Nikolay Tzankov (NMNHS; 1977-2016) also finds of unidentified cobras (Elapidae F. Boie, 1827) and skinks (Scincidae Gray, 1825) were confirmed (N. Tzankov, unpubl. data).

First data on the composition of the bird fauna of the locality were published by Boev (1996, 1998a, b). A total of 101 avian finds of 15 taxa have been collected: Botaurinae gen., Geronticus balcanicus Boev, 1998, Anas sp., cf. Aquilinae gen., Falco sp. ex. gr. tinnunculus, Chauvireria sp. n., Turdus cf. philomelos, Turdidae gen., Coccothraustes balcanicus Boev, 1998, Corvus sp. ex gr. monedula, Pyrrhocorax sp.,

Received: 16 June 2019 • Editor: Peter Shurulinkov 
aff. Lullula sp., Emberiza sp., Corvus aff. praecorax, Corvus sp., Corvidae gen., Oscines fam., Aves indet. (Boev, 2002). In addition, ten years later a species of woodlark - Lullula slivnicensis Boev, 2012, has been described.

The uncovered Macromammalian fauna is rich: Canis ex gr. etruscus Major, 1877, Vulpes cf. alopecoides, Hyaenidae gen., Meles thorali Viret, 1951, Lutrinae gen., Panthera cf. gombaszoegensis Kretzoi, 1938, Homotherium crenatidens Fabrini, 1890, Cervus philisi Schaub, 1941, Eucladoceros cf. senezensis Deperet, 1910, Gazellospira cf. torticornis (Aymard, 1854), Procamtoceras cf. brivatense Schaub, 1923, Gallogoral meneghinii (Rutimeyer, 1878), Pliotragus cf. ardeus (Deperet, 1884), Megalovis sp., Soergelia aff. minor Moya-Sola, 1987, Hemitragus sp. n., ? Ovis sp., Bovidae gen. et sp. indet. (two species), and Equus cf. stenonis Cocchi, 1867 (Spassov, 1997).

\section{Material and methods}

The author collected the examined material in 1993 during seven days of excavations on 08.06.1993; 07.07.1993; 20.07.1993; 27.07.1993; 24-25.08.1993 and 17.09.1993. The collected finds represented 54 unarticulated bones with a minimum number of at least four individuals (NMNHS 3060-3113; 3115) (Boev, 1999).

All measurements are given in millimetres and follow Boev (1997) (Tables 1-12). The taxonomy follows Mlíkovský (2002) and Dickinson \& Remsen (2013). The osteological terminology is after Baumel \& Witmer (1993).

Abbreviations: Anatomical: a. - articularis; c. condylus; cmc - carpometacarpus; dex. - dextra; dist. - distalis; f. - facies; hum. - humeralis; lat. - lateral, lateralis; met. - metacarpale, metacarpalis; pr. - processus.; prox. - proximalis; sin - sinistra; tbt - tibiotarsus; tmt - tarsometatarsus; vent. - ventralis; Institutional: MNHNP - Muséum national d'histoire naturelle, Paris; NMNH - National Museum of Natural History (Smithsonian Institution), Washington; NHMT - Natural History Museum, Tring; NMNHS - National Museum of Natural History (Bulgarian Academy of Sciences), Sofia; RMNH - Nationaal Naturhistorisch Museum, Leiden; UCBL - Université Claude Bernard - Lyon 1; UMMZ - University of Michigan, Museum of Zoology (Ann Arbor - Michigan).

\section{Systematic part}

All the 21 skeletal elements morphologically (and morphometrically) resemble the homologous elements of partridges, quails and francolins, i. e. to small-sized phasianids. No species of small phasianids in the fossil record of Europe and the Middle East of the same or similar size are known except Chauvireria balcanica Boev, 1997, the only species of genus Chauvireria.

\section{Order: GALLIFORMES (Temminck, 1820) \\ Family: Phasianidae Horsfield, 1821 \\ Subfamily: Phasianinae Horsfield, 1821 \\ Genus Chauvireria Boev, 1997}

\section{Chauvireria bulgarica sp. $\mathrm{n}$.}

Synonymy: Chauvireria sp. n. (Boev, 2002). Holotype: scapula sin., cranial part, NMNHS 3100 (Plate 1: a-c), collected on 7 July 1993 by Z. Boev.

Locality: A destroyed cave in a rocky hill in the operating area of the Kozyaka stone quarry (Fig. 1), 3 $\mathrm{km}$ WNW from the town of Slivnitsa (Sofia Region; Fig. 2); FN 64; 42.51 N, 23.00 E; 650 m a.s.1. Early Pleistocene (the final of the Middle Villafranchian; Villanyian; first half of MNQ 18 a (Spassov, 1998). Recently, the site was dated between ca. 2.1 and 1.95 Ma (Spassov, 2016).

Horizon: Unconsolidated, unstratified bone elements accumulated in the filling of clay terra-rossa. Most of the fossil bones were broken. All finds were disarticulated. The bone material was collected from the transported and dumped mass of stones and soil in the quarry (Boev, 1998a).

Chronology: Early Pleistocene, end of middle Villafranchian (Villanian), end of MN 17 - early MN 18 zone; ca. 1.85 Mya (Spassov, 1997; Vasil Popov - unpubl. data). Spassov (1998) established the age as MNQ 18a (= Senèze) after the chronostratigraphical scheme of Guerin (1990). Studies that are more recent, date the site's deposits at 2.1-1.95 Mya (Spassov, 2016).

Etymology: The name "bulgarica" is given after the name of the state of Bulgaria, where the finds originated from.

Paratypes: Forelimb and pectoral girdle: cmc dex. dist., NMNHS 3081; cmc sin. dist., NMNHS 3113; cmc sin. prox., NMNHS 3068 (Plate 1: g); cmc dex. 
dist., NMNHS 3084; coracoid dex. dist., NMNHS 3065; coracoid dex. dist., NMNHS 3066 (Plate 1: h); coracoid sin. dist., NMNHS 3074 (Plate 1: h); coracoid sin. dist., NMNHS 3083 (Plate 1: h); furcula prox., NMNHS 3067 (Plate 1: i, j); humerus dex. dist., NMNHS 3063 (Plate 1: d, e); phalanx prox. dig. maj. dex., NMNHS 3080; phalanx prox. dig. maj. sin., NMNHS 3070; phalanx prox. dig. maj. sin., NMNHS 3071 (Plate 1: 1); radius dex. prox., NMNHS 3064 (Plate 1: k); radius dex. prox., NMNHS 3079 (Plate 1: k); scapula dex., NMNHS 3102; sternum (pars rostralis), NMNHS 3115; ulna dex. dist., NMNHS 3076 (Plate 1: g); ulna dex. prox., NMNHS 3072; ulna dex. dist., NMNHS 3062; ulnare dex. NMNHS 3101 (Plate 1: $\mathrm{m}$ ); hindlimb and pelvic girdle: femur sin. dist., NMNHS 3099 (Plate 2: a, b); phalanx dig. pedis, NMNHS 3085-3098, 3107-3110 (Plate 2: m, n); tbt dex. dist., NMNHS 3077; tbt sin. dist., NMNHS 3082; tbt. dex. dist., NMNHS 3060 (Plate 2: c, d); tbt. sin. dist., NMNHS 3061(Plate 2: e); tmt dex. dist., NMNHS 3111; tmt dex. prox., NMNHS 3069 (Plate 2: f, g); tmt sin prox., NMNHS 3075; tmt sin prox., NMNHS 3104; tmt sin. dist., NMNHS 3078 (Plate 2: i, j); tmt sin. dist., NMNHS 3105; tmt sin. prox., NMNHS 3073 (Plate 2: k, 1); tmt sin. prox., NMNHS 3112; tmt sin., dist., NMNHS 3103; tmt dex. dist., NMNHS 3106.

Diagnose: A small phasianid of subfamily Phasianinae, differing from the type species (Chauvireria balcanica Boev, 1998) of the genus by: (1) the longer acromion scapulae, which is more upright and dorsally, instead of cranially directed, (2) the thinner humeral part of the coracoid, and (3) the wider condylus dorsalis of the humerus.

Comparison: The articular surface of the scapula differs from that of Ammoperdix griseogularis Brandt, 1843 by the sharper acromion. It differs from C. balcanica by the longer acromion, which is more upright and dorsally, instead cranially, directed. (Plate 1: a). This feature is very clear. It differs from A. heyi (Temminck, 1825) by the wider f. a. hum. and the longer acromion. Chauvireria bulgarica sp. $\mathrm{n}$. has the longest acromion of all compared small phasianids (see below). It is distinguished from Ptilopachus petrosus Gmelin, 1789 by the bigger f. a. clavicularis and the less sharpened caudal edge of the f. a. hum., as well as by the absence of the fovea between the humeral and clavicular articular surfaces. The new species differs from Synoicus ypsilophorus (Bosc, 1792) by the bigger size (Table 1) and the more square than triangle

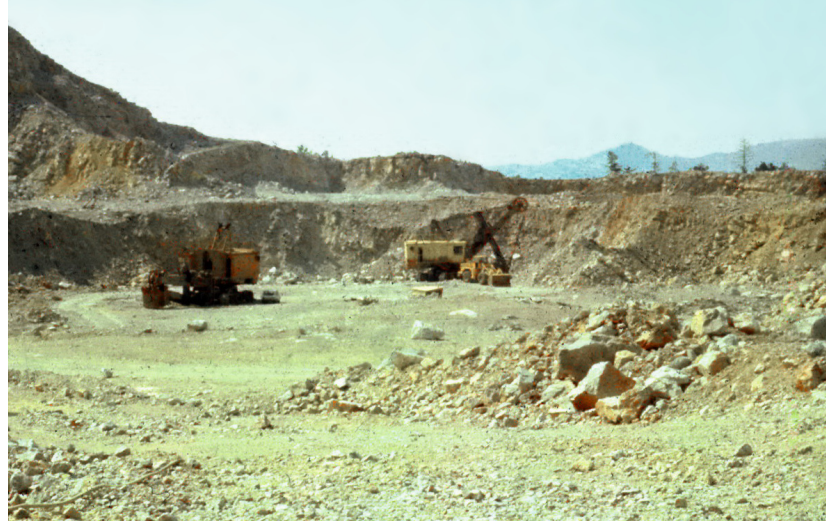

Fig. 1. Part of the operating area of the Kozyaka stone quarry in the vicinities of the town of Slivnitsa, 8 June 1993, Photo: Z. Boev.

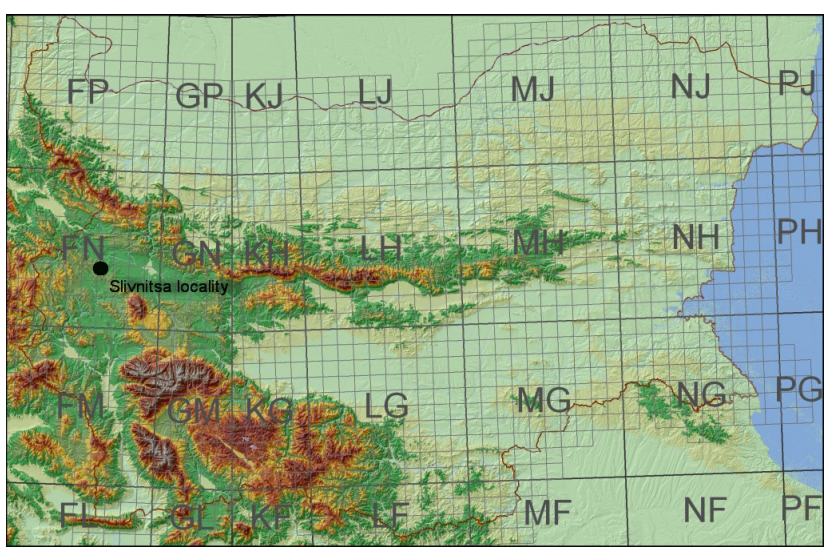

Fig. 2. Location of the Kozyaka quarry (Slivnitsa locality, as known in the literature) in Bulgaria.

f. a. hum. It differs from Caloperdix oculeus (Temminck, 1815) by the smaller dimensions, the longer and thinner $f$. a. clavicularis and the sharper ventromedial angle of $\mathrm{f}$. a. hum.

\section{Comparison of other skeletal elements}

- Forelimb and pectoral girdle

Humerus (Plate 1: d, e; Table 2): C. bulgarica sp. n. differs from $C$. balcanica by the wider c. dorsalis. It differs from A. griseogularis by the more round $\mathrm{c}$. dorsalis. Metrically it approaches to $C$. balcanica. It is smaller than A. griseogularis. At the same time, it differs from C. balcanica and A. griseogularis by the deeper sulcus humerotricipitalis. Chauvireria bul- 


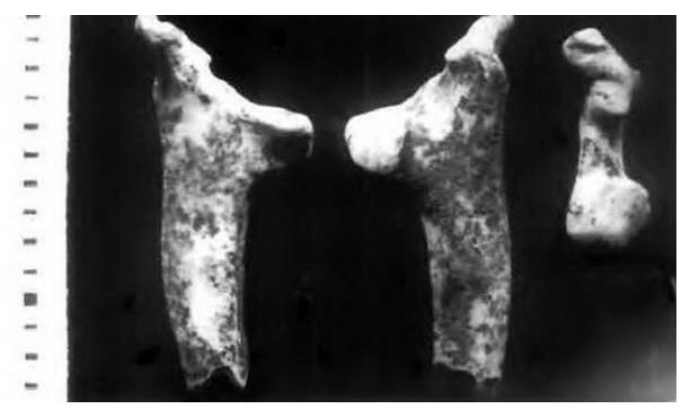

a
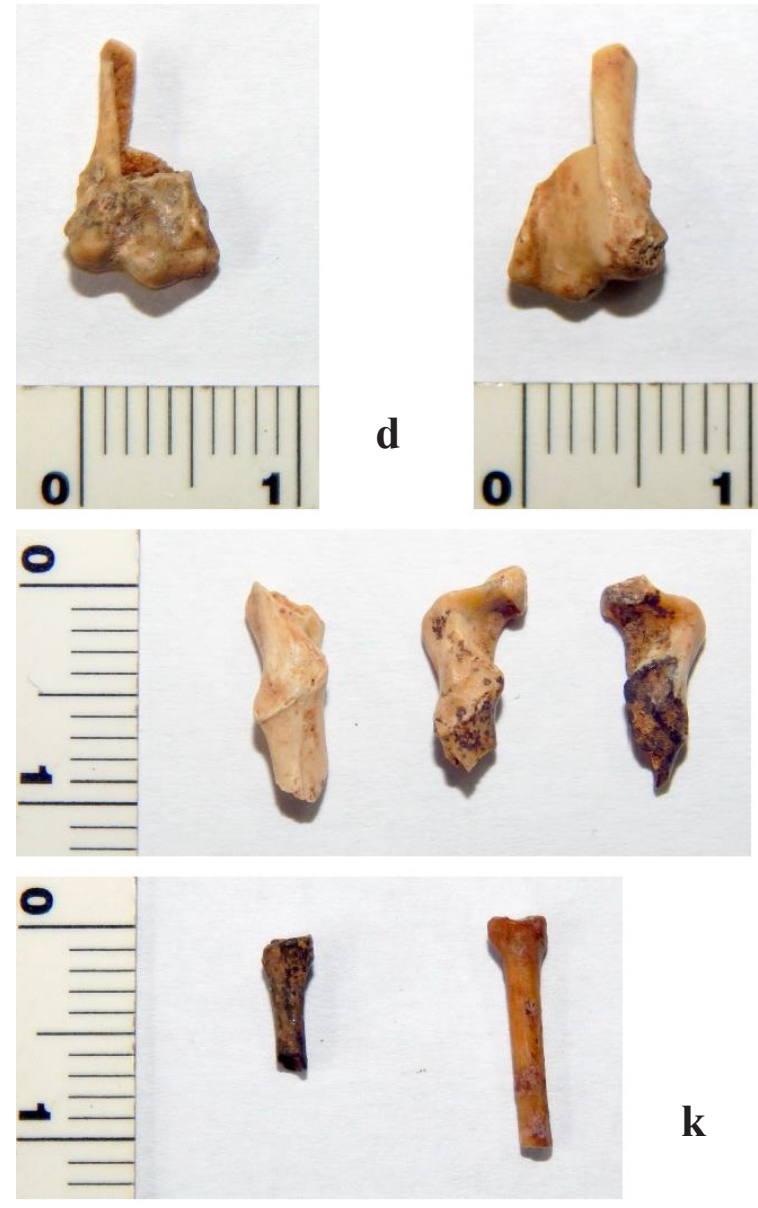

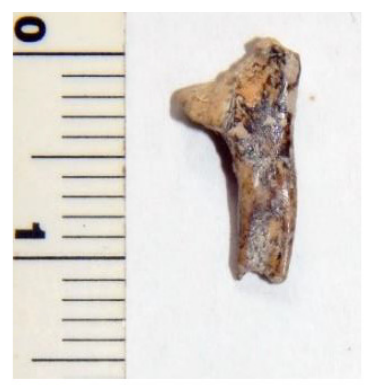

b
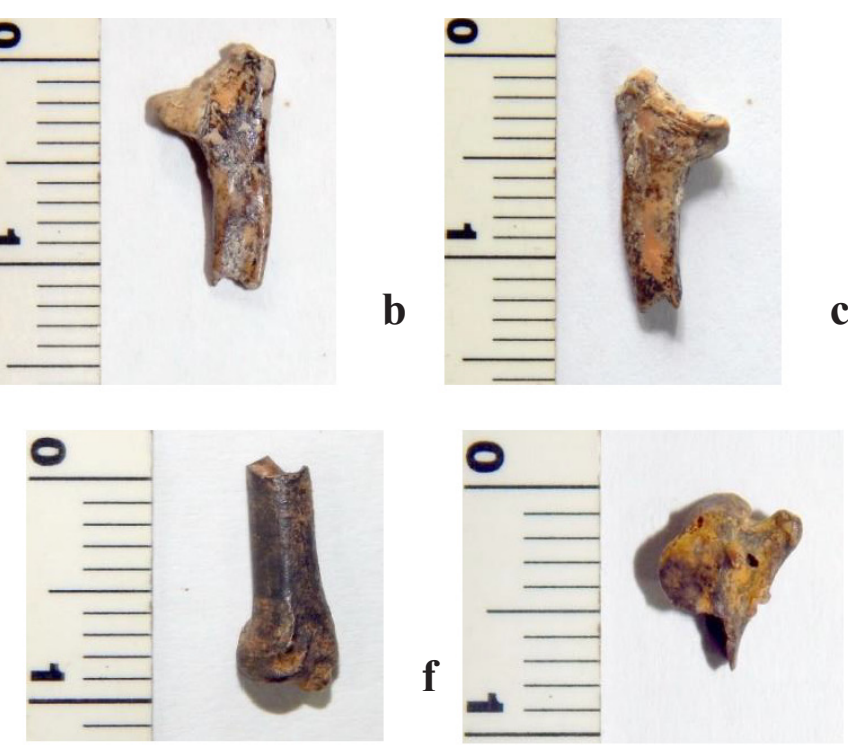

Plate 1. Chauvireria bulgarica sp. n. - skeleton elements of forelimb and pectoral girdle: holotype, scapula sin., cranial part, NMNHS 3100: a - photographs of 1998 of Boris Andreev (left to right): medial, lateral and cranial views; b - medial view; c - lateral view; paratypes: humerus dex.dist., NMNHS 3063: d - lateral view; e - medial view; f - ulna dex.dist., NMNHS 3076 - lateral view; g - carpometacarpus sin. prox., NMMNS 3068 - medial view; $\mathrm{h}$ - coracoids (humeral parts) - medial views (left to right): NMMNS 3083, NMMNS 3066, NMMNS 3074; furcula (symphysal part), NMNHS 3067: i - caudal view; $\mathrm{j}$ - right lateral view; $\mathrm{k}$ - radius prox. (left to right): NMMNS 3079, NMMNS 3064; 1 - phalanx prox. dig.maj. sin., NMNHS 3071 - lateral view; m - os ulnare sin., NMNHS 3101 - lateral view. Photos: Z. Boev.

garica sp. n. differs from Ammoperdix by the thinner connection of $\mathrm{c}$. vent. with epic. vent. and by the shallower fossa olecrani. Chauvireria bulgarica sp. n. differs from Pt. petrosus by the narrower distal epiph- ysis, the more rounded c. dorsalis, the smaller dorsocaudal inclination of the distal epiphysis towards the axis of diaphysis. Chauvireria bulgarica sp. n. differs from Synoicus ypsilophorus by the more rhomboid- 
shaped, rather than rounded, pr. flexorius in ventral view. The compared species differs from $C$. oculeus by the smaller dimensions, smaller pr. flexorius, as well as by the shallower fossa olecrani.

Radius (Plate 1: k; Table 3): C. bulgarica $\mathrm{sp.} \mathrm{n}$. differs from $C$. balcanica by the more protruding tuberculum bicipitale radii and the narrower cotyla hum. It differs from $A$. griseogularis by the less protruding tuberculum bicipitale radii and the narrower cotyla hum. From $A$. heyi the compared species differs by the narrower longitudinal ridge on the medio-cranial surface in the prox. half of diaphysis. From Ptilopachus it differs by the narrower prox. epiphysis, and the more developed tuberculum bicipitale radialis. From $S$. ypsilophorus it differs by the more rounded, instead of oval, cotyla hum. and the bigger size. It differs from C. oculeus by the smaller dimensions and the less developed tuberculum bicipitale radii.

Coracoid (Plate 1: h; Table 4): C. bulgarica sp. n. differs from A. griseogularis metrically (it is smaller). Its prox. part is much thinner. It is thinner even than that of $C$. balcanica and the hook of pr. acrocoracoideus is more prominent. F. a. hum. of C. bulgarica sp. n. is more concave. The impressio ligamenti acrocoracoidei is narrower and shallower than that of $A$. griseogularis. It differs from $A$. heyi by the narrower acrocoracoidal part and the bigger hook of pr. acrocoracoideus and the deeper impressio ligamenti acrocoracohumeralis. Ammoperdix heyi has a dent on the hook of pr. acrocoracoideus. Ptilopachus differs from C. bulgarica sp. $\mathrm{n}$. by the lacking of a hook of pr. acrocoracoideus and the rounded acrocoracoid, as well as by the lighter medio-lateral inclination in cranial view and the less protruded latero-caudal ridge of $\mathrm{f}$. a. hum. S. ypsilophorus differs from C. bulgarica sp. n. by the smaller sizes, the lacking hook of pr. acrocoracoideus and the less concave f. a. clavicularis. Chauvireria bulgarica sp. $\mathrm{n}$. differs from C. oculeus by its smaller size, the lacking hook of pr. acrocoracoideus, the stronger caudal bend of f. a. hum. and the stronger cranio-lateral inclination of $f$. a. clavicularis.

Cmc (Plate 1: g; Table 5): The new species from Slivnitsa locality is smaller than A. griseogularis and C. balcanica. It differs by the almost perpendicular cranial ridge of pr. extensorius towards the axis of os met. majus. Its pr. pisiformis protrudes less than in C. balcanica. Its trochlea carpalis is narrower and in cranial profile it is almost even or slightly protruding, but it is not concave as in A. griseogularis. It is also concave in C. balcanica. Os met. majus is straighter and thinner in the distal end than in C. balcanica and A. griseogularis. Chauvireria bulgarica sp. $\mathrm{n}$. has the deepest sulcus interosseus in comparison with the other two species. It differs from $A$. heyi by the thinner pr. extensorius in cranial view, the better-expressed ridge between the cranio-lateral and the dorsal surface of os met. majus, the shorter synostosis of met. dist., the deeper fovea between $\mathrm{f}$. a. dist. of os met. majus and $\mathrm{f}$. a. dist. of os met. minus, the deeper fovea between the os $\mathrm{m}$. majus and os $\mathrm{m}$. minus on the ventral surface of the distal end. It differs from Ptilopachus in the sharper and more cranially positioned pr. pisiformis, the sharper pr. extensorius, the narrower trochlea carpalis (3.2 $\mathrm{mm}$ and $2.6 \mathrm{~mm}$, respectively) and the narrower dist. epiphysis. It differs from $S$. ypsilophorus by the straighter instead of concave latero-cranial ridge of proc. extensorius and the straighter diaphysis of os met. majus. It differs from C. oculeus by the sharper pr. extensorius, the straighter diaphysis of the os met. majus, a less prominent in caudo-lateral direction facies articlaris distalis metacarpalis minus, and the sharper pr. pisiformis.

Ulna (Plate 1: f; Table 6): $C$. bulgarica sp. n. differs from $C$. balcanica by the smaller dimensions, blunter and more round dist. end of impressio brachialis, smaller tuberculum carpale, and the shallower incissura tendinea. It differs from $A$. griseogularis by the smaller size and the sharper prominent distally condylus ventralis ulnaris. It is distinguished from $A$. heyi by the sharper edge between c. dorsalis ulnaris and diaphysis and sharp strongly protruding caudally c. vent. ulnaris and the shallower fovea. The described new species of Chauvireria differs from Ptilopachus by the narrower dist. epiphysis, narrower and longer c. vent. ulnaris and by the presence of a dent. It differs from S. ypsilophorus by the higher and sharper c. vent. ulnaris, bigger size, and the more round shape of c. dorsalis ulnaris. It also differs from C. oculeus by the smaller dimensions, the longer c. vent. ulnaris, the shallower depressio radialis, and the more rounded instead of a triangle-shaped cross-section of the diaphysis in its distal end.

Furcula (Plate 1: i, j; Table 7): C. bulgarica $\mathrm{sp.}$ n. differs from A. griseogularis and resembles C. balcanica by the ribbing of the hypocleidium in lateral view. In contrast to $A$. griseogularis its symphysis furculae is concave in cranial view instead protruding at the base of the hypocleidium. C. balcanica differs by the steeper caudal orientation of the caudal ridge of hypocleidium and thus resembling to A. griseogu- 
laris. It differs from $A$. heyi by the lacking of a cranial concaveness in lateral view and the wider symphysis in frontal view. It differs from C. oculeus by the concave cranial surface of symphysis furculae and the smaller size.

Ulnare (Plate 1: $\mathrm{m}$; Table 8): C. bulgarica $\mathrm{sp} . \mathrm{n}$. differs from Ammoperdix heyi by the longer and thinner horn and bigger symphysal part -2.5 and $2.0 \mathrm{~mm}$ respectively.

Phalanx proximalis digitis majoris (Plate $1: 1 ; \mathrm{Ta}-$ ble 9): $C$. bulgarica sp. n. differs from $A$. griseogularis and $C$. balcanica by the longer fovea in the dist. end on the lateral (dorsal) side, the thinner ventral ribbing ridge on the medial (ventral) side. It differs from $A$. heyi by the relatively wider phalanx in the middle (4.2 and 3.75 and 3.7) and by the deeper fovea on the f. vent. (medialis). It differs from Ptilopachus by the longer phalanx, the shallower cut of the ventr. part. The compared species differs from S. ypsilophorus by the arc-like ventro-caudal edge, the larger size and more protruding caudally tip backwards. It differs from C. oculeus by the more elongated phalanx in lateral view, smaller size, more concave caudal half of the latero-caudal surface.

\section{- Hindlimb and pelvic girdle}

Femur (Plate 2: a, b; Table 10): C. bulgarica sp. n. differs from $C$. balcanica and A. griseogularis by the deeper fossa poplitea, bigger cranio-caudal dimension, and the thinner c. medialis in cranial view. It differs from $A$. heyi by the more round c. medialis, the straighter transition of the condyle to the diaphysis, the shallower impressio ligamenti cruciati cranialis. From Ptilopachus the species differs by the narrower sulcus intercondylaris and the less developed crista tibiofibularis. It differs from $S$. ypsilophorus by the deeper fossa poplitea and the more round c. medialis in medial view. It differs from C. oculeus by the shallower fossa poplitea and the relatively narrower and deeper sulcus intercondylaris.

Tbt (Plate 2: c-e; Table 11): C. bulgarica sp. n. metrically fits in the range of the type species $C$. balcanica. C. bulgarica sp. n. differs from C. balcanica by the longer pons supratendineus, wider dist. opening of incissura supratendinea, the sharper verge and the deeper incissura intercondylaris. It differs from $C$. balcanica and $A$. griseogularis by the smaller epicondylus medialis and the shallower and wider intercon- dylar space. The compared species differs from $A$. heyi by the smaller epicondylus medialis, the round instead straight ridge of pons supratendineus, the shallower incissura intercondylaris, and the longer and narrower incissura tendinea lat. over distal epiphysis. Differences from Ptilopachus: narrower dist. epiphysis, narrower dist. opening of pons supratendineus, narrower sulcus extensorius, pons supratendineus, incissura intercondylaris, prox. epiphysis, area intercondylaris and the shorter crista cnemialis cranialis, as well as the smaller diameters of c. lat. and c. medialis. It differs from S. ypsilophorus by the oval instead round profile of c. lat., less concaved pons supratendineus, larger epicondylus lat., more elongated cranio-caudally f. a. proximalis. It differs from $C$. oculeus by the relatively deeper incissura intercondylaris, more prominent instead concave pons supratendineus, more clearly shaped epicondylus lat., narrower prox. epiphysis, less developed longitudinal ribbing of $\mathrm{f}$. caudalis in the middle part of diaphysis.

Tmt (Plate 2: f-1; Table 12): C. bulgarica $\mathrm{sp}$. n. differs from $C$. balcanica by the more angular instead of the round cotyla medialis in dorsal view. This makes it look more similar to A. griseogularis, although it differs from that species metrically and by the narrower hypotarsus. In comparison to both species of genus Ammoperdix, C. bulgarica sp. $\mathrm{n}$. has lower eminentia intercondylaris and wider foramen vasculare distale. It differs from $A$. heyi by the less concave cotyla medialis, the narrower trochlea metatarsi III, and narrower incissura intertrochlearis medialis. It differs from Ptilopachus by the smaller foramen vasculare distale, narrower epiphysis and diaphysis (the whole bone is more gracile), lower crista medialis hypotarsi, a lower cotyla medialis (its medial ridge), a less developed crista plantares medialis and crista lateralis, and a less prominent trochlea metatarsi III over tr. metatarsi II and IV. It differs from S. ypsilophorus by the larger size and the more proximally positioned $\mathrm{f}$. vas. distale, the relatively narrower hypotarsus and the more rounded cotyla medialis in dorsal view. From C. oculeus it differs by the smaller size, and the lacking of a longitudinal ridge on the crista medialis hypotarsi on the caudal side of the diaphysis, the more proximally positioned foramen vasculare distale, as well as the straighter, instead of a rounded, lateral edge of cotyla lateralis.

Phalanx I dig. 1 pedis (Plate 2: $\mathrm{m}-$ left): C. bulgarica sp. n. differs from $C$. balcanica by the relatively wider distal end of diaphysis just before the trochlea. 


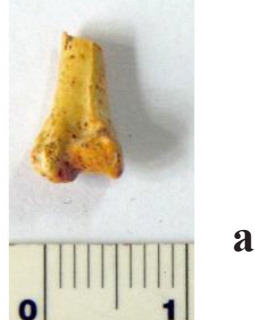

$\mathbf{a}$
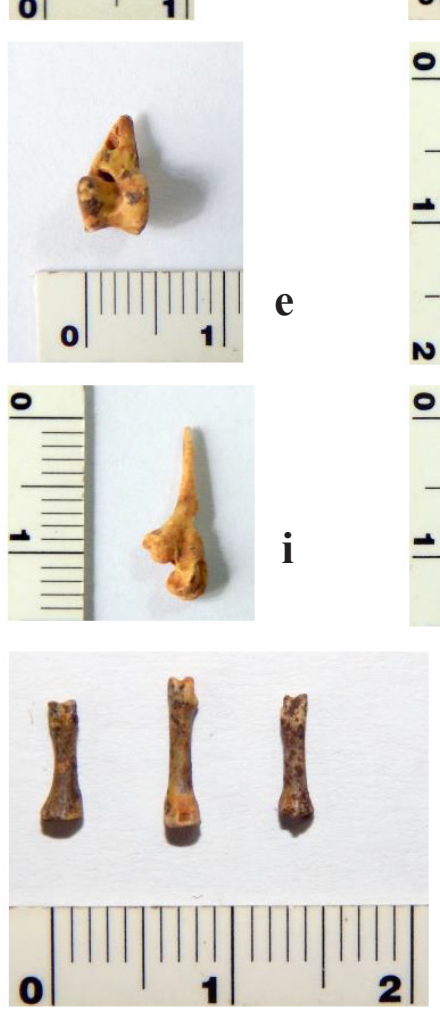

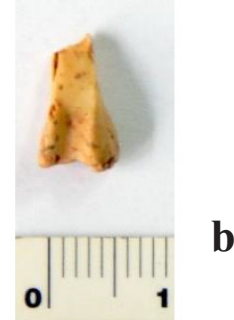

b
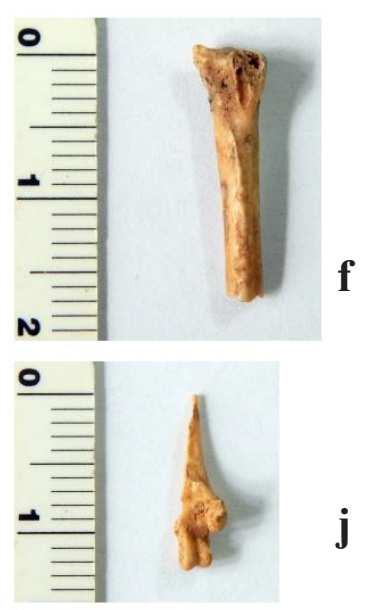

m
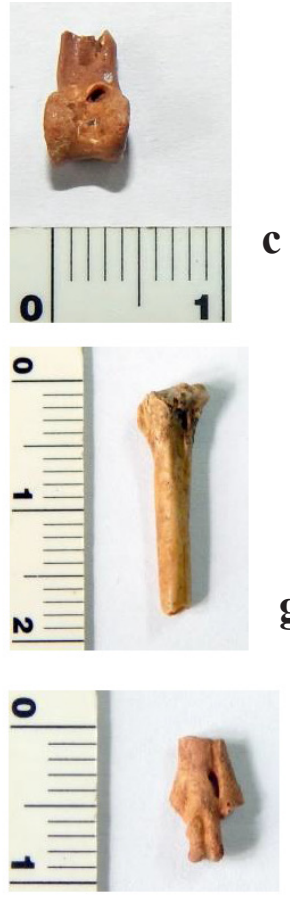

$\mathbf{k}$
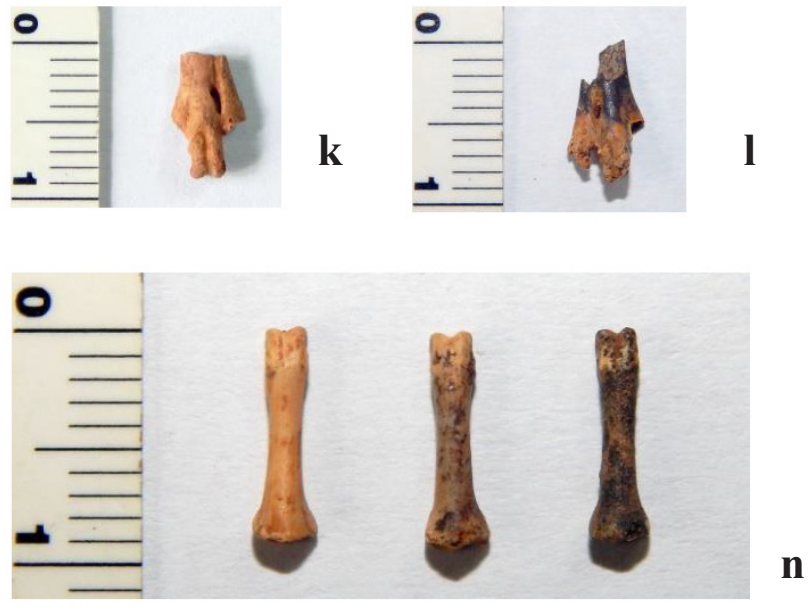

Plate 2. Chauvireria bulgarica sp. n. - skeleton elements of hindlimb and pelvic girdle: paratypes: femur sin. dist., NMNHS 3099: a - cranial view; b - caudal view; tibiotarsus dex. dist., NMNHS 3060: c - cranial view; d - cranio-lateral view; e tibiotarsus dist., NMNHS 3061 - cranial view; tarsometatarsus dex. prox., NMNHS 3069: f - cranio-lateral view; g - caudal view; h - tarsometatarsus dex. prox., NMNHS 3075 - cranio-lateral view; tarsometatarsus dex. dist., NMNHS 3078: $\mathrm{i}$ - lateral view; j - caudal view; $\mathrm{k}$ - tarsometatarsus sin. dist., NMNHS 3073 - cranial view; 1 - tarsometatarsus dex. dist., NMNHS 3106 - cranial view; $m$ - phalanges digitorum pedis (left to right): NMNHS 3085, NMNHS 3087, NMNHS 3088 - dorsal views; $\mathrm{n}$ - phalanges digitorum pedis (left to right): NMNHS 3107, NMNHS 3108, NMNHS 3110 - dorsal view. Photos: Z. Boev.

It differs from $A$. griseogularis by the higher vault of the phalanx, as well as metrically. It differs from Coturnix coturnix (Linnaeus, 1758) by the triangular instead of a heart-shaped profile of f. art. prox., as well as dimensionally. It differs from $A$. heyi in the longer phalanx and the more symmetrical trochlea.

Phalanx I dig. 2 pedis (Plate 2: $\mathrm{m}$ - middle): It differs from $C$. coturnix by the deeper fovea. From $A$. griseogularis it differs by the smaller size, the shallower intercondylar sulcus of the trochlea and the ventrally lowered trochlea in the dist. end.which is slightly prominent in A. griseogularis. The Bulgarian Chauvireria differs from A. heyi by the narrower trochlea and the relatively thinner phalangeal body.

Phalanx II dig. 2 pedis (Plate 2: $\mathrm{m}$ - rigth): $C$. bulgarica sp. n. differs from A. heyi by the relatively smaller proximal thickness.

Phalanx I dig. 3 pedis (Plate 2: $\mathrm{n}-$ left, middle, right): C. bulgarica sp. n. differs from Ammoperdix griseogularis by the triangular and more asymmetri- 
cal shape, instead of a heart-like shape, of the f. art. prox.

Phalanx II dig. 3 pedis: C. bulgarica sp. n. differs from $A$. heyi by the narrower trochlea and the thinner phalangeal body ("diaphysis"). It differs from A. griseogularis by the smaller size, more elongated trochlea and the shallower facies articularis proximalis in its ventral end. It differs from $C$. balcanica by the narrower phalangeal body in its distal end and the thicker lat. "condyle".

Phalanx III dig. 3 pedis (Plate 2: $\mathrm{m}-$ right): $C$. bulgarica sp. n. differs from C. balcanica by the lower f. a. prox. and the narrower trochlea phalangis.

Phalanx I dig. 4 pedis: $C$. bulgarica $\mathrm{sp}$. n. differs from $C$. balcanica by the more rounded heart-like profile contour of $f$. a. prox. and the deeper fovea on the ventral surface of the distal end.

Phalanx II dig. 4 pedis: $C$. bulgarica sp. n. differs from $C$. balcanica by the thinner prox. part, the smaller f. a. prox. and the smaller trochlea. It differs from $A$. griseogularis by the smaller size and the lack of ventral longitudinal ridges.

Phalanx III dig. 4 pedis: C. bulgarica sp. n. differs from $A$. griseogularis by the relatively longer widening of $f$. a. prox. of its dorsal end and the more conically, instead of constricted, shape of the middle of the phalangeal body. It differs from C. balcanica by the heart-like profile of $\mathrm{f}$. art. prox. and the thicker corpus phalangis.

\section{Conclusions}

Chauvireria bulgarica sp. $\mathrm{n}$. is the second known species in the genus. The type species, C. balcanica Boev 1997 was described also from the early Pleistocene of W Bulgaria and the deposits of its fossil remains are also dated to the middle Villafranchian (MN 17; $2.5-$ 2.3 Mya; Spassov, 2016). Chauvireria bulgarica sp. n. lived at least ca. 0.4 Mya later than C. balcanica. In general, $C$. bulgarica sp. $\mathrm{n}$. is slightly smaller than the older C. balcanica (Tables 1-4, 6-12).

Chauvireria bulgarica, in comparison to other species (C. balcanica), inhabited less forested landscape, although it was recorded also in dry xerophytic open habitats. We know that also rocky massifs and lakes existed in the region of the site. The dominance of (both in species and in finds) Bovidae (Caprinae) over Cervidae suggests more open environments. "The more intense drying in Slivnitsa in comparison with Varshets ought to be connected mainly with the climatic landscape changes in the time." (Spassov, 1997: 675). Numerous chauvirerias (C. balcanica in Varshets locality and C. bulgarica sp. n. in Slivnitsa locality) possibly disappeared because of the changes of grass vegetation or forests expansion before the first cooling of the Pleistocene. Obviously, they both have played an important role in the palaeornithocoenoses as an abundant and accessible prey for the large nocturnal raptors. Large owls (eagle owls of the genus Bubo Duméril, 1805) were the most probable agent for the accumulation of their fossil bones in the former caves of both localities.

\section{Acknowledgements}

The author is very grateful to Dr Cécile MourerChauviré (University Claude Bernard - Lyon) for the opportunity to work at the UCBL on fossil birds of Bulgaria. This work was partially sponsored by the Fondation Scientifique de Lyon et du Sud-Est (Lyon) and the Bulgarian National Science Fund (Sofia) (grant No B-202/1992). Special thanks to Dr Hanneke Meijer and an anonymous reviewer for their useful reviews of the earlier version of the manuscript.

\section{References}

Baumel J.J., Witmer L.M. 1993 Osteologia. In: Baumel J., King A., Breazile J., Evans H., Vanden Berge J. (eds). Handbook of avian anatomy: Nomina Anatomica Avium. Pub. Nutall Orn. Cl. 23. Cambridge, Massachusetts, 45-132.

Bochenski Z. 1997 List of European fossil bird species. Acta zoologica cracoviensia 40 (2): 293333.

Boev Z. 1996 Tertiary avian localities of Bulgaria. In: Mlikovsky, J. (ed.) Tertiary avian localities of Europe. Acta universitatis Carolinae Geologica. Univerzita Karlova. Praha, 39 (1995): 541-545.

Boev Z. 1997 Chauvireria balcanica gen. n., sp. n. (Phasianidae - Galliformes) from the Middle Villafranchian of Western Bulgaria. Geologica Balcanica 27 (3-4): 69-78.

Boev Z. 1998a Presence of Bald Ibises (Geronticus Wagler, 1832) (Threskiornithidae - Aves) in the Late Pliocene of Bulgaria. Geologica Balcanica 28 (1-2): 45-52. 
Boev Z. 1998b Late Pliocene Hawfinches (Coccothraustes Brisson, 1760) (Aves: Fringillidae) from Bulgaria. Historia naturalis bulgarica 9: 87-99.

Boev Z. 1999 Neogene and Quaternary birds (Aves) from Bulgaria. - National Museum of Natural History, Bulg. Acad. of Sci., Sofia. D. Sci. Thesis. Volume I. Basic Part. 1-243; Volume II. Supplement 1 - Figures, 1-135; Volume II. Supplement 2 - Tables, 1-108. (In Bulgarian)

Boev Z. 2002 Neogene avifauna of Bulgaria. In: Zhou Z., Zhang F. (eds) Proceedings of the 5th Symposium of the Society of Avian Palaeontology and Evolution, Beijing, 01-04.06.2000. Science Press, Beijing, 29-40.

Boev Z. 2012 Neogene Larks (Aves: Alaudidae (Vigors, 1825) from Bulgaria. Acta zoologica bulgarica 64 (3): 295-318.

Brodkorb P. 1964 Catalogue of fossil birds. Part 2 (Anseriformes through Galliformes). Bulletin of the Florida State Museum. Biological sciences, 8 (3): 195-336.

Dickinson E.C., Remsen Jr. J.V. (eds) 2013 The Howard \& Moore Complete Checklist of the Birds of the World. 4th Edition, Vol. 1, Aves Press, Eastboume, U.K., $461 \mathrm{pp}$.

Livezey B.C., Zusi R.L. 2006 Higher-order phylogeny of modern birds (Theropoda, Aves: Neornithes) based on comparative anatomy: I. Methods and Characters. Bulletin of Carnegie Museum of Natural History 37: 1-544.

McCowan P.J. 1994 Family Phasianidae (Pheasants and Partridges). In: del Hoyo J., Elliott A., Sargatal J. (eds). Handbook of the Birds of the World. Vol. 2. New World Vulturcs to Guineafowl. Lynx Edicions, Barcelona, 434-553.

Mlíkovský J. 2002 Cenozoic Birds of the World. Part 1: Europe. Praha: Ninox Press, 1-406.

Spassov N. 1997 The Villafranchian Mammalian fauna and its investigation in Europe, on the Balkans and in Bulgaria. Geologica balcanica 27 (3-4): 83-94.

Spassov N. 1998 Villafranchian succession of mammalian megafaunas from Bulgaria and the biozonation of South-East Europe. In: Aguilar J.P., Legendre S., Michaux J. (eds) Actes du Congres BiochroM'97, Mem. Trav. E.P.H.E., Inst. Montpellier 21: 669-676.

Spassov N. 2016 Southeastern Europe as a Route for the Earliest Dispersal of Homo toward Europe: Ecological Conditions and the Timing of the First Human Occupation of Europe. In: Harvati K., Roksandic M. (eds), Paleoanthropology of the Balkans and Anatolia, Vertebrate Paleobiology and Paleoanthropology, Springer Science + Business Media Dordrecht 2016, 281-290. DOI: 10.1007/978-94-024-0874-4_16 
Appendices
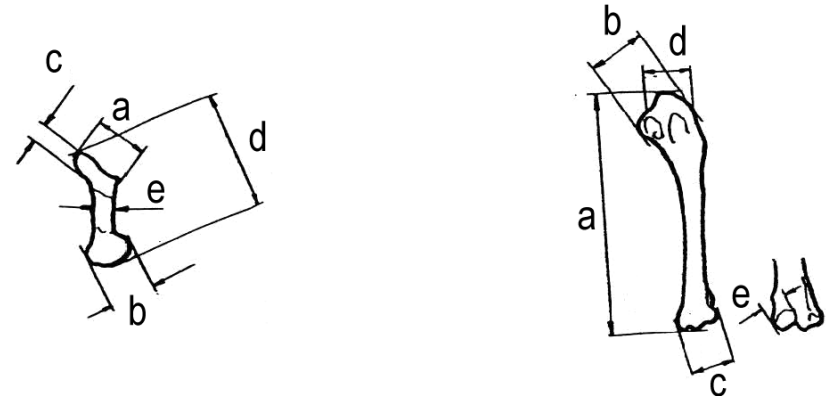

A
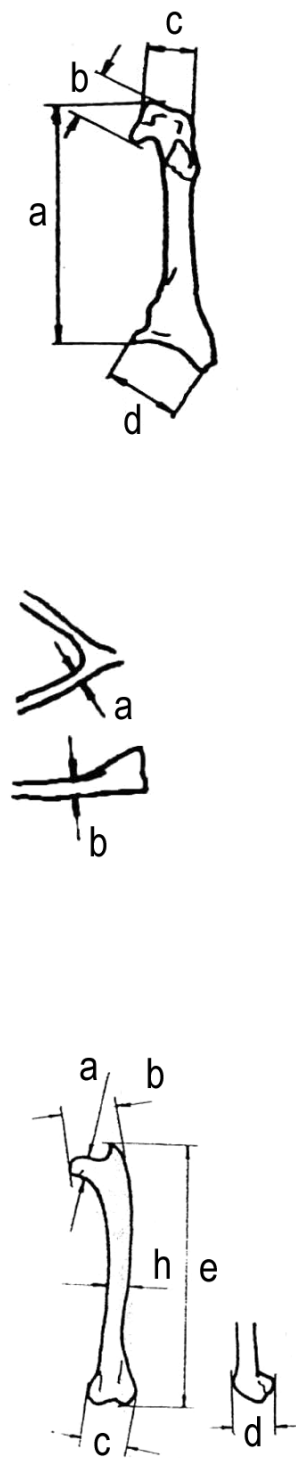
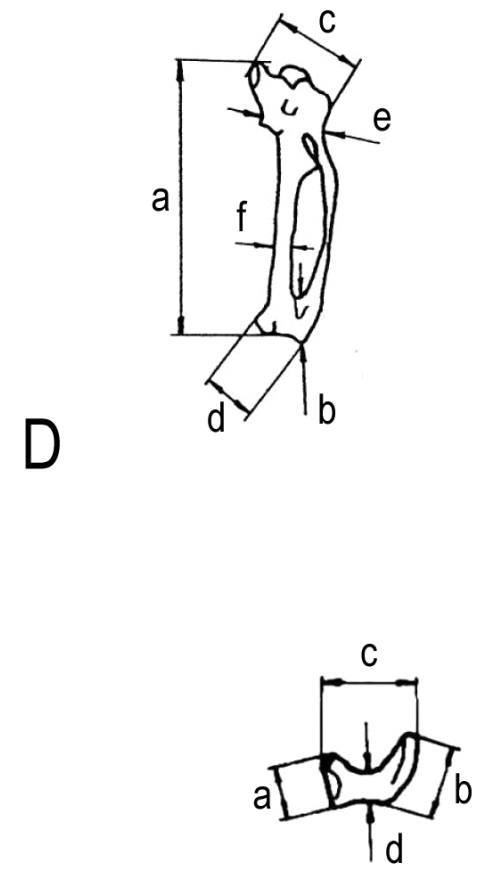

G

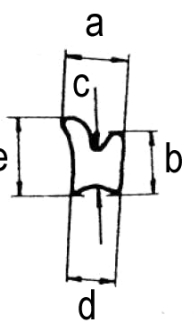

B

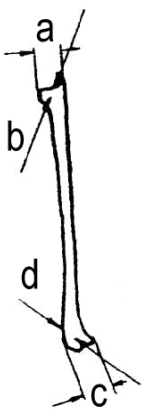

C

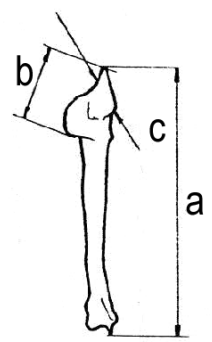

$E$

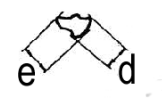

F

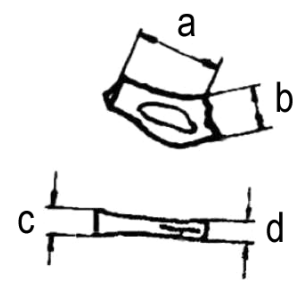

H

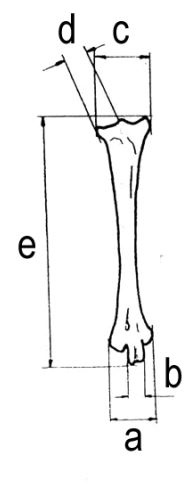

Plate 3 
Chauvireria bulgarica sp. n. - an extinct Early Pleistocene small phasianid from Bulgaria

Table 1. Measurements of scapula in fossil and recent small phasianids (ref. to Plate $3-\mathrm{A}$ )

\begin{tabular}{|c|c|c|c|c|c|}
\hline Species & a & $\mathrm{b}$ & c & $\mathrm{d}$ & e \\
\hline \multicolumn{6}{|l|}{ Fossil - Slivnitsa, Varshets } \\
\hline Chauvireria bulgarica sp. n. NMNHS 3100 & 3.1 & 3.5 & 1.6 & 7.8 & 1.6 \\
\hline Chauvireria bulgarica sp. n. NMNHS 3102 & - & 3.4 & 1.5 & - & - \\
\hline Chauvireria balcanica NMNHS & $3.43(46)$ & $3.66(55)$ & $1.61(45)$ & $7.51(44)$ & $1.53(54)$ \\
\hline \multicolumn{6}{|l|}{ Recent } \\
\hline Ammoperdix griseogularis NMNH 429687 & 2.8 & 3.9 & 2.0 & 7.7 & 1.3 \\
\hline Ammoperdix heyi RMNH 771 & 2.2 & 3.1 & 1.5 & 6.15 & 1.2 \\
\hline Ammoperdix heyi MNHNP 1878/484 & 2.6 & 3.5 & 1.7 & 6.75 & 1.25 \\
\hline Caloperdix oculea RMNH 7654 & 3.0 & 4.2 & 1.6 & 8.9 & 1.7 \\
\hline Rollulus rouroul NMNH 490663 & 2.7 & 3.7 & 2.1 & 7.4 & 1.8 \\
\hline Melanoperdix nigra NMNH 321114 & 3.2 & 3.1 & 2.0 & 8.0 & 1.7 \\
\hline Bambusicola thoracica NMNH 318741 & 3.0 & ca. 3.9 & ca. 1.8 & 7.2 & - \\
\hline Francolinus francolinus NMNH 491380 & 3.4 & 3.0 & 2.5 & 8.0 & 1.6 \\
\hline Arborophila brunneopectus NMNH 491868 & 5.3 & 5.3 & 2.6 & 8.7 & 1.8 \\
\hline Ptilopachus petrosus MNHNP 1878/409 & 2.7 & 3.15 & 1.6 & 7.4 & 1.35 \\
\hline Ptilopachus petrosus UMMZ 223/611 & 2.9 & 2.95 & 1.8 & 6.6 & 1.2 \\
\hline Synoicus ypsilophorus UMMZ 214/161 & 2.9 & 2.65 & 1.3 & 4.7 & 1.15 \\
\hline Synoicus ypsilophorus NHMT HB 198 & 3.3 & 2.3 & 1.2 & 4.9 & 1.2 \\
\hline
\end{tabular}

Table 2. Measurements of humerus in fossil and recent small phasianids (ref. to Plate $3-\mathrm{B}$ )

Species

a

b

c

d

e

Fossil - Slivnitsa, Varshets

Chauvireria bulgarica sp. n. NMNHS 3063

Chauvireria balcanica NMNHS

Palaeocryptonyx edwardsi UCBL

Palaeocryptonyx edwardsi UCBL

Palaeocryptonyx edwardsi UCBL

Palaeocryptonyx gaiardi UCBL

Palaeocryptonyx grivensis UCBL

\begin{tabular}{rr}
\hline & \\
$40.4(9)$ & $10.56(38)$ \\
45.25 & 12.4 \\
46.4 & 11.7 \\
44.8 & 12.4 \\
46.0 & 13.0 \\
37.0 & 10.0 \\
& \\
40.0 & 10.9 \\
36.1 & 9.7 \\
36.9 & 10.2 \\
46.3 & 12.1 \\
42.5 & 11.8 \\
43.8 & 11.5 \\
42.1 & 10.3 \\
46.0 & 13.0 \\
34.95 & 9.85 \\
36.3 & 9.0 \\
31.35 & 7.15 \\
31.6 & 7.2
\end{tabular}

Recent

Ammoperdix griseogularis NMNH 429687

Ammoperdix heyi RMNH 771

Ammoperdix heyi MNHNP 1878/484

Caloperdix oculea RMNH 7654

Rollulus rouroul NMNH 490663

Melanoperdix nigra NMNH 321114

Bambusicola thoracica NMNH 318741

Arborophila brunneopectus NMNH 491868

Ptilopachus petrosus MNHNP 1878/409

Ptilopachus petrosus UMMZ 223/611

Synoicus ypsilophorus UMMZ 214/161

Synoicus ypsilophorus NHMT HB 198

31.6

10.9

9.7

10.2

12.1

11.8

11.5

10.3

13.0

9.85

9.0

7.15

7.2

7.0
$7.43(53)$
9.0
8.6
8.6
9.0
7.0

8.5
7.5
7.9
9.9
8.7
9.5
8.7
10.2
7.8
7.6
5.6
5.5

$7.53(37)$
9.4
9.3
9.1
-
-

7.8
7.4
7.65
9.2
8.8
7.8
7.7
9.0
7.4
7.2
5.4
5.25

5.25

4.95

5.2

$-$

4.0

4.5

4.3

4.35

4.8

5.0

4.5

4.4

5.2

4.15

4.05

3.2

3.0 
Table 3. Measurements of radius in fossil and recent small phasianids (ref. to Plate $3-\mathrm{C}$ )

\begin{tabular}{|c|c|c|c|c|c|}
\hline Species & a & $\mathrm{b}$ & $\mathrm{c}$ & $\mathrm{d}$ & e \\
\hline \multicolumn{6}{|l|}{ Fossil - Slivnitsa, Varshets } \\
\hline Chauvireria bulgarica sp. n. NMNHS 3079 & 2.4 & 2.9 & - & - & - \\
\hline Chauvireria bulgarica sp. n. NMNHS 3064 & 2.4 & 3.0 & - & - & - \\
\hline Chauvireria balcanica NMNHS & $2.63(34)$ & $3.02(33)$ & $3.33(28)$ & $2.06(29)$ & $33.41(4)$ \\
\hline \multicolumn{6}{|l|}{ Recent } \\
\hline Ammoperdix griseogularis NMNH 429687 & 2.8 & 3.4 & 3.4 & 2.0 & 35.1 \\
\hline Ammoperdix heyi RMNH 771 & 2.35 & 2.9 & 3.3 & 1.75 & 32.1 \\
\hline Ammoperdix heyi MNHNP 1878/484 & 2.6 & 3.1 & 3.5 & 1.9 & 32.6 \\
\hline Caloperdix oculea RMNH 7654 & 3.2 & 3.9 & 4.5 & 2.2 & 41.0 \\
\hline Rollulus rouroul NMNH 490663 & 3.0 & 3.3 & 4.0 & 3.5 & 37.7 \\
\hline Melanoperdix nigra NMNH 321114 & 3.0 & 3.6 & 4.1 & 2.4 & 38.3 \\
\hline Bambusicola thoracica NMNH 318741 & 2.7 & 3.2 & 4.1 & 2.2 & 35.7 \\
\hline Francolinus francolinus NMNH 491380 & 3.2 & 3.9 & 4.4 & 2.4 & 36.2 \\
\hline Arborophila brunneopectus NMNH 491868 & 3.4 & 4.1 & 3.6 & 2.3 & 41.0 \\
\hline Ptilopachus petrosus MNHNP 1878/409 & 2.6 & 3.1 & 3.85 & 2.1 & 30.0 \\
\hline Ptilopachus petrosus UMMZ 223/611 & 2.5 & 3.1 & 3.6 & 2.1 & 30.0 \\
\hline Synoicus ypsilophorus UMMZ 214/161 & 1.8 & 2.2 & 2.65 & 1.55 & 25.0 \\
\hline Synoicus ypsilophorus NHMT HB 198 & 1.8 & 2.2 & 2.6 & 1.45 & 24.2 \\
\hline
\end{tabular}

Table 4. Measurements of coracoid in fossil and recent small phasianids (ref. to Plate $3-\mathrm{D}$ )

Species

a b

c

d

e

Fossil - Slivnitsa, Varshets

Chauvireria bulgarica sp. n. NMNHS 3066

Chauvireria bulgarica sp. n. NMNHS 3083

Chauvireria bulgarica sp. n. NMNHS 3065

Chauvireria balcanica NMNHS

Recent

Ammoperdix griseogularis NMNH 429687

Ammoperdix heyi RMNH 771

Ammoperdix heyi MNHNP 1878/484

Caloperdix oculea RMNH 7654

Rollulus rouroul NMNH 490663

Melanoperdix nigra NMNH 321114

Bambusicola thoracica NMNH 318741

Francolinus francolinus NMNH 491380

Arborophila brunneopectus NMNH 491868

Ptilopachus petrosus MNHNP 1878/409

Ptilopachus petrosus UMMZ 223/611

Synoicus ypsilophorus UMMZ 214/161

Synoicus ypsilophorus NHMT HB 198

\begin{tabular}{|c|c|c|c|c|}
\hline - & 2.1 & 5.0 & - & - \\
\hline - & 2.1 & 5.3 & - & - \\
\hline - & 2.0 & 5.0 & - & - \\
\hline 27.27 (14) & $4.19(40)$ & $5.91(46)$ & $7.98(31)$ & $2.06(39)$ \\
\hline 30.0 & 3.0 & 6.6 & 7.9 & 2.1 \\
\hline 26.99 & 2.6 & 5.3 & 6.0 & 2.05 \\
\hline 28.0 & 2.0 & 5.6 & 6.2 & 2.3 \\
\hline 33.85 & 2.9 & 5.8 & 7.75 & 2.4 \\
\hline 31.8 & 2.6 & 5.8 & 7.1 & 2.1 \\
\hline 32.2 & 3.0 & 6.2 & 7.8 & 2.5 \\
\hline ca. 31.0 & ca. 3.2 & ca. 5.9 & ca. 6.9 & - \\
\hline ca. 35.0 & 3.0 & 7.3 & 7.2 & 2.4 \\
\hline 35.8 & 3.1 & 7.1 & 8.5 & 2.5 \\
\hline 26.5 & 2.1 & 5.5 & 6.6 & 2.2 \\
\hline 28.0 & 2.15 & 5.5 & 6.0 & 2.2 \\
\hline 22.5 & 1.8 & 4.0 & 4.5 & 2.0 \\
\hline 22.3 & 1.8 & 3.9 & 4.2 & 1.7 \\
\hline
\end{tabular}


Chauvireria bulgarica sp. n. - an extinct Early Pleistocene small phasianid from Bulgaria

Table 5. Measurements of cmc in Chauvireria bulgarica sp. n. (ref. to Plate $3-\mathrm{E}$ )

Species

Fossil - Slivnitsa

Chauvireria bulgarica sp. n. NMNHS 3068

Chauvireria bulgarica sp. n. NMNHS 3113

Chauvireria bulgarica sp. n. NMNHS 3081 a b

c

d e

f

$\begin{array}{rrrrrr}-\overline{3} & - & 6.1 & - & \text { ca. } 4.3 & - \\ \text { ca. } & - & - & - & - & 1.6 \\ - & 4.6 & - & 4.0 & - & 1.9\end{array}$

Table 6. Measurements of ulna in fossil and recent small phasianids (ref. to Plate $3-\mathrm{F}$ )

Species

Fossil - Slivnitsa, Varshets

Chauvireria bulgarica sp. n. NMNHS 3076

Chauvireria bulgarica sp. n. NMNHS 3072

Chauvireria balcanica NMNHS

Recent

Ammoperdix griseogularis NMNH 429687

Ammoperdix heyi RMNH 771

Ammoperdix heyi MNHNP 1878/484

Caloperdix oculea RMNH 7654

Rollulus rouroul NMNH 490663

Melanoperdix nigra NMNH 321114

Bambusicola thoracica NMNH 318741

Francolinus francolinus NMNH 491380

Arborophila brunneopectus MNHW 491868

Ptilopachus petrosus MNHNP 1878/409

Ptilopachus petrosus UMMZ 223/611

Synoicus ypsilophorus UMMZ 214/161

Synoicus ypsilophorus NHMT HB 198 a

-
$36.81(8)$
39.5
35.5
36.2
45.3
41.5
42.4
39.1
39.8
45.8
32.9
32.7
22.6
26.6

b

-
$6.78(46)$

7.2
6.5
6.7
8.6
7.8
8.0
7.1
8.2
9.0
6.1
5.75
4.7
4.7

c d

e

4.1

$\begin{array}{rr}4.0 & 3.7 \\ (48) & 2.56(46)\end{array}$

$5.24(45)$

$4.26(48)$

4.9

4.4

4.7

4.4

3.9

4.1

4.2

4.6

5.75

5.3

4.8

5.0

4.9

5.0

5.0

5.2

4.9

5.5

4.7

4.3

5.0

5.9

4.2

4.0

3.9

3.1

6.1

5.2

5.7

4.2

4.05

4.5

3.5

3.2

3.0

Table 7. Measurements of furcula in fossil and recent small phasianids (ref. to Plate $3-\mathrm{G}$ )

Species

a

Fossil - Slivnitsa, Varshets

Chauvireria bulgarica sp. n. NMNHS 3067

ca. 1.00

Chauvireria balcanica NMNHS

Recent

Ammoperdix griseogularis NMNH 429687

Ammoperdix heyi RMNH 771

Ammoperdix heyi MNHNP 1878/484

Caloperdix oculea RMNH 7654

Rollulus rouroul NMNH 490663

Melanoperdix nigra NMNH 321114

Bambusicola thoracica NMNH 318741

Francolinus francolinus NMNH 491380

Arborophila brunneopectus NMNH 491868

Ptilopachus petrosus UMMZ 223/611

Synoicus ypsilophorus UMMZ 214/161

Synoicus ypsilophorus NHMT HB 198 
Zlatozar Boev

Table 8. Measurements of ulnare in fossil and recent small phasianids (ref. to Plate $3-\mathrm{H}$ )

Species

Fossil - Slivnitsa, Varshets

Chauvireria bulgarica sp. n. NMNHS 3101

Chauvireria balcanica NMNHS

Recent

Ptilopachus petrosus UMMZ 223/611

Synoicus ypsilophorus UMMZ 214/161

Synoicus ypsilophorus NHMT HB 198 a

3.4

$3.27(8)$

3.5

b

4.6
3.2

3.35

3.0

2.6

3.0 c

d
4.1

$4.18(8)$

4.05

3.2

2.6
2.5

$2.32(8)$

2.0

1.85

ca. 1.8

Table 9. Measurements of phalanx proximalis digitis majoris in fossil and recent small phasianids (ref. to Plate 3 - I)

Species

Fossil - Slivnitsa, Varshets

Chauvireria bulgarica sp. n. NMNHS 3070

Chauvireria bulgarica sp. n. NMNHS 3080

Chauvireria bulgarica sp. n. NMNHS 3071

Chauvireria balcanica NMNHS

\section{Recent}

Ammoperdix griseogularis NMNH 429687

Ammoperdix heyi RMNH 771

Ammoperdix heyi MNHNP 1878/484

Caloperdix oculea RMNH 7654

Rollulus rouroul NMNH 490663

Melanoperdix nigra NMNH 321114

Bambusicola thoracica NMNH 318741

Francolinus francolinus NMNH 491380

Arborophila brunneopectus NMNH 491868

Ptilopachus petrosus MNHNP 1878/409

Ptilopachus petrosus UMMZ 223/611

Synoicus ypsilophorus UMMZ 214/161

Synoicus ypsilophorus NHMT HB 198 $\mathrm{a}$

8.5

8.5

8.35

$8.64(27)$

6.25

$\begin{array}{rrrr}9.1 & 3.7 & 3.2 & 2.1 \\ 7.95 & 3.3 & 2.4 & 1.6 \\ 9.3 & 3.4 & 2.65 & 1.75 \\ 8.85 & 3.05 & 3.0 & 2.4 \\ 7.4 & 4.8 & 2.8 & 2.0 \\ 8.0 & 4.9 & 3.1 & 2.2 \\ 8.2 & 4.1 & 2.8 & 1.95 \\ 9.0 & 4.75 & 3.4 & 2.3 \\ 8.3 & 4.7 & 3.35 & 2.3 \\ 7.0 & 3.3 & 2.65 & 1.9 \\ 6.4 & 2.9 & 2.6 & 1.7 \\ 6.15 & 2.4 & 1.9 & 1.4 \\ 6.25 & 2.5 & 2.1 & 1.25\end{array}$

b

d

1.8

$2.12(26)$

$4.07(26) \quad 3.0(28) \quad 2.12(26)$


Chauvireria bulgarica sp. n. - an extinct Early Pleistocene small phasianid from Bulgaria

Table 10. Measurements of femur in fossil and recent small phasianids (ref. to Plate $3-\mathrm{J}$ )

Species

Fossil - Slivnitsa, Varshets

Chauvireria bulgarica sp. n. NMNHS 3099

Chauvireria balcanica NMNHS

Recent

Ammoperdix griseogularis NMNH 429687

Ammoperdix heyi RMNH 771

Ammoperdix heyi MNHNP 1878/484

Caloperdix oculea RMNH 7654

Rollulus rouroul NMNH 490663

Melanoperdix nigra NMNH 321114

Bambusicola thoracica NMNH 318741

Francolinus francolinus NMNH 491380

Arborophila brunneopectus NMNH 491868

Ptilopachus petrosus MNHNP 1878/409

Ptilopachus petrosus UMMZ 223/611

Synoicus ypsilophorus UMMZ 214/161

Synoicus ypsilophorus NHMT HB 198 a $\quad$ b $\quad$ c

$\begin{array}{rrr}-86(27) & -29(26) & 6.53(39) \\ & & \\ 2.9 & 8.6 & 7.5 \\ 2.5 & 7.6 & 6.95 \\ 2.7 & 7.7 & 6.95 \\ 3.5 & 9.85 & 9.2 \\ 3.5 & 8.5 & 8.2 \\ 2.9 & 8.8 & 8.2 \\ 3.2 & 8.4 & 7.8 \\ 3.7 & 9.3 & 8.8 \\ 4.3 & 9.8 & 9.9 \\ 2.6 & 7.6 & 7.1 \\ 2.95 & 7.45 & 7.7 \\ 2.1 & 5.8 & 5.2 \\ 2.4 & 5.6 & 5.0\end{array}$

d e f

$\begin{array}{rrr}4.8 & - & -\end{array}$

$\begin{array}{rrr}6.0 & 43.0 & 3.0 \\ 5.3 & 39.9 & 3.4 \\ 5.55 & 42.5 & 3.15 \\ 7.8 & 51.9 & 3.6 \\ 7.2 & 49.1 & 3.0 \\ 7.3 & 48.3 & 3.5 \\ 7.2 & 48.0 & 3.6 \\ 6.5 & 52.8 & 3.6 \\ 7.1 & 52.8 & 3.9 \\ 5.75 & 41.1 & 3.3 \\ 5.95 & 43.7 & 3.25 \\ 3.9 & 35.5 & 2.4 \\ 4.0 & 39.5 & 2.3\end{array}$

Table 11. Measurements of tbt in fossil and recent small phasianids (ref. to Plate $3-\mathrm{K}$ )

\begin{tabular}{|c|c|c|c|c|c|c|c|c|}
\hline Species & $\mathrm{a}$ & $\mathrm{b}$ & $\mathrm{c}$ & d & e & $\mathrm{f}$ & g & $\mathrm{h}$ \\
\hline \multicolumn{9}{|l|}{ Fossil - Slivnitsa, Varshets } \\
\hline Chauvireria bulgarica sp. n. NMNHS 3061 & 5.1 & ca. 4.7 & 3.5 & 4.3 & - & - & - & - \\
\hline Chauvireria bulgarica sp. n. NMNHS 3077 & - & ca. 4.6 & 3.3 & - & - & - & - & - \\
\hline Chauvireria bulgarica sp. n. NMNHS 3060 & 4.9 & 4.5 & 3.4 & 3.9 & 5.0 & - & - & - \\
\hline Chauvireria balcanica NMNHS & $5.02(45)$ & $4.73(44)$ & $3.65(41)$ & $4.28(39)$ & $5.23(42)$ & $5.26(24)$ & $7.34(25)$ & $5.74(24)$ \\
\hline \multicolumn{9}{|l|}{ Recent } \\
\hline Ammoperdix griseogularis NMNH 429687 & 5.4 & 5.4 & ca. 3.9 & 4.3 & 5.7 & 6.1 & 8.3 & 6.1 \\
\hline Ammoperdix heyi RMNH 771 & 5.3 & 4.85 & 3.6 & 4.0 & 5.4 & 5.4 & 7.7 & 6.05 \\
\hline Ammoperdix heyi MNHNP 1878/484 & 5.3 & 4.8 & 3.6 & 4.05 & 5.4 & 5.5 & 7.4 & ca. 6.1 \\
\hline Caloperdix oculea RMNH 7654 & 6.5 & 6.5 & 4.7 & 5.2 & 7.0 & 7.1 & 9.3 & 7.9 \\
\hline Rollulus rouroul NMNH 490663 & 6.4 & 5.8 & 3.9 & 5.1 & 6.2 & 6.9 & 9.5 & 7.3 \\
\hline Melanoperdix nigra NMNH 321114 & 6.0 & 5.8 & 4.5 & 4.6 & 6.3 & 6.5 & 8.6 & 6.5 \\
\hline Bambusicola thoracica NMNH 318741 & 5.9 & 5.9 & 4.3 & 4.9 & 6.0 & 7.0 & 9.0 & 6.4 \\
\hline Francolinus francolinus NMNH 491380 & 8.2 & 6.9 & 4.7 & 6.0 & 7.2 & 8.0 & 9.1 & 7.9 \\
\hline Arborophila brunneopectus NMNH 491868 & 7.4 & 7.0 & 4.9 & 5.6 & 7.4 & 7.9 & 9.9 & 8.9 \\
\hline Ptilopachus petrosus MNHNP 1878/409 & 5.7 & 5.05 & 3.6 & 4.5 & 5.35 & 5.95 & 8.9 & 6.9 \\
\hline Ptilopachus petrosus UMMZ 223/611 & 5.75 & 5.0 & 3.25 & 4.3 & 5.2 & 6.6 & 8.3 & 6.85 \\
\hline Synoicus ypsilophorus UMMZ 214/161 & 4.1 & 3.85 & 3.2 & 3.35 & 4.2 & 4.4 & 6.1 & 4.5 \\
\hline Synoicus ypsilophorus NHMT HB 198 & 4.3 & 3.8 & 3.1 & 3.3 & 4.05 & 4.2 & 5.75 & 4.5 \\
\hline
\end{tabular}


Zlatozar Boev

Table 12. Measurements of tmt in fossil and recent small phasianids (ref. to Plate $3-\mathrm{L}$ )

\begin{tabular}{|c|c|c|c|c|c|}
\hline Species & $\mathrm{a}$ & $\mathrm{b}$ & $\mathrm{c}$ & d & e \\
\hline \multicolumn{6}{|l|}{ Fossil - Slivnitsa, Varshets } \\
\hline Chauvireria bulgarica sp. n. NMNHS 3069 & - & - & - & 3.2 & - \\
\hline Chauvireria bulgarica sp. n. NMNHS 3075 & - & - & ca. 4.9 & 3.1 & - \\
\hline Chauvireria bulgarica sp. n. NMNHS 3078 & - & 2.3 & - & - & - \\
\hline Chauvireria bulgarica sp. n. NMNHS 3073 & - & 2.25 & - & - & - \\
\hline Chauvireria balcanica NMNHS & $5.67(25)$ & $2.29(31)$ & $5.55(32)$ & $3.67(32)$ & $28.43(6)$ \\
\hline \multicolumn{6}{|l|}{ Recent } \\
\hline Ammoperdix griseogularis NMNH 429687 & 6.4 & 2.6 & 5.8 & 3.9 & 34.5 \\
\hline Ammoperdix heyi RMNH 771 & 6.3 & 2.4 & 5.95 & 3.6 & 32.0 \\
\hline Ammoperdix heyi MNHNP 1878/484 & 6.6 & 2.4 & 5.6 & 3.85 & 32.8 \\
\hline Caloperdix oculea RMNH 7654 & 7.7 & 3.0 & 7.6 & 4.6 & 48.05 \\
\hline Rollulus rouroul NMNH 490663 & 7.1 & 2.7 & 7.0 & 4.0 & 44.9 \\
\hline Melanoperdix nigra NMNH 321114 & 7.1 & 2.6 & 6.4 & 4.0 & 46.2 \\
\hline Bambusicola thoracica NMNH 318741 & 6.8 & 2.7 & 6.7 & ca. 4.3 & 42.0 \\
\hline Francolinus francolinus NMNH 491380 & 7.7 & 3.3 & 8.6 & 5.5 & 43.0 \\
\hline Arborophila brunneopectus NMNH 491868 & 8.6 & 3.5 & 8.8 & 5.2 & 42.8 \\
\hline Ptilopachus petrosus MNHNP 1878/409 & 6.35 & 2.45 & 6.1 & 3.5 & 30.75 \\
\hline Ptilopachus petrosus UMMZ 223/611 & 6.3 & 2.45 & 6.1 & 3.7 & 31.9 \\
\hline Synoicus ypsilophorus UMMZ 214/161 & 4.85 & 2.0 & 4.5 & 2.9 & 24.2 \\
\hline Synoicus ypsilophorus NHMT HB 198 & 4.6 & 2.0 & 4.5 & 2.9 & 23.0 \\
\hline
\end{tabular}

